sidered that its arcuate shape can be best explained as a major $D_{2}$ neutral fold with one hinge in the Imarssuaq lake and another just under the margin of the Inland Ice and probably containing the Isua ore body. The major folds are calculated as plunging steeply $\mathrm{E}$ to SE with steep easterly dipping and NNE-SSW trending axial planes.

The tangential dykes appear to have been intruded during a late stage of the $D_{2}$ episode, whilst the radial set are thought to belong to a later tensile phase. Finally, semi-ductile shearing and brittle truncation of the western arm left the supracrustal belt in its present form.

Dept. of Earth Sicences, University of Leeds, Leeds LS2 9JT, U.K.

\title{
Field mapping of Bjørneøen and the adjacent coast of Nordlandet, Godthåbsfjord, southern West Greenland
}

\section{Patrick R. James}

Mapping at a scale of 1:50000 was carried out on the gneisses and supracrustals of Bjørneøen and the granulites of the adjacent east coast of Nordlandet; the area has previously been described by Noe-Nygaard \& Ramberg (1961) and Bridgwater \& McGregor (1974). During the present study special emphasis was placed on the structural relationships of the various rock units and also on the relationship and contact between the amphibolite facies and granulite facies areas. A short excursion was made at the beginning of the field season around Godthabsfjord and Ameralik with the helpful guidance of V. R. McGregor whose kind assistance is especially acknowledged.

\section{Malene supracrustals}

Supracrustals of mainly basic and ultrabasic, volcanic and intrusive origin, and occasional minor sedimentary units, form a large part of both the Bjørneøen and eastern Nordlandet sequences. On Bjørneøen there is a major supracrustal pile which reaches nearly $1 \mathrm{~km}$ in thickness at its maximum on the south Bjørneøen coast. In various forms this pile caps most of the major $1000^{+} \mathrm{m}$ peaks of the island. Other supracrustals on Bjørneøen and on the coast of Nordlandet occur in bands up to $100 \mathrm{~m}$ in width and also minor pods and lenses enclosed in gneisses.

The ultrabasic rocks and related talc schists usually stand out due to their relative greater competence and resistance to erosion. A locality of pillowed ultrabasic was discovered on the plateau east of Qârusûp qáqâ. The basic supracrustal igneous rocks consist of banded, green and black, massive and pillowed amphibolites, fine grained, black amphibolites, occasional green, garnet rich diopside bands and lenses, and frequent large sheets and horizons of instrusive coarse metagabbro (leopard rock). Paler, intermediate igneous rocks are also interbanded with the basics and occasionally 
grade into distinctive coarse agglomeratic horizons with matrix supported, well rounded pebbles and fragments.

True metasediments are rarely recognized on Bjørneøen, but are represented by thin, rusty, garnet bearing, pelite horizons within the supracrustal pile. A very distinctive garnet rich, quartzo-feldspathic unit associated with mafic granulites occurs on the east side of Sârdlup taserssua inland from the coast of Nordlandet.

Only a few minor pods of anorthosite and anorthosite metagabbro have been found on Qôrnoq, north-east Bjørneøen, although this suite is found extensively on Storø to the east.

\section{Nûk gneisses}

Apart from a thin strip on the south coast, all of the quartzo-feldspathic gneisses on Bjørneøen and the orthogneisses and orthogranulites of Nordlandet lack the distinctive discordant Ameralik dykes found to the south on Sadeløen and in increasing numbers farther east. All units are therefore considered to be part of the Nûk intrusive gneissic suite of McGregor (1973). The Nûk suite is a complex of banded and homogeneous acidic and intermediate gneisses with a remarkable variety of associated minor intrusives, most of which have to a greater or lesser extent suffered postemplacement ductile deformation. The gneisses at present may be differentiated on mainly lithological grounds into an early heterogeneous suite and a later homogeneous granodiorite suite.

The earlier heterogeneous gneisses are the dominant phase in the west, though decreasing in total gneiss proportion towards the east. They are found mainly on the east coast of Nordlandet, the west coast of Bjørneøen and in a thin strip up to $300 \mathrm{~m}$ above sea level on the east Bjørneøen coast. The gneisses are banded and streaky, mainly acidic with later intermediate dioritic phases. They typically contain large numbers of supracrustal enclaves and smaller remnants in various stages of digestion and deformation; they are also characterised by a multiplicity of minor instrusives including white migmatitic veins and veinlets, and acidic and intermediate sheets and dykes.

With the decrease in the proportion of heterogeneous gneisses from west to east there is a concomitant increase in the amount of later homogeneous gneiss. These gneisses dominate on the east coast of Bjørneøen where they adjoin and are intrusive into the major Malene pile. On the plateau east of Qârusûp qáqâ ultrabasic pods, amphibolite bands and other supracrustal relics 'float' in a sea of homogeneous gneisses. Laterally extensive gneiss sheets up to $10 \mathrm{~m}$ in thickness also invade the supracrustal pile especially south of Naqerdloq kangigdleq. The homogeneous gneisses are coarse, white, hornblende-biotite granodioritic rocks characterised by a distinct lack of later minor instrusives.

The lack of conclusive intrusive relations between the earlier heterogeneous gneisses and the major supracrustal pile suggests that this pile may represent a suite of supracrustals later in time than those contained as bands and inclusions within the earlier gneisses.

The orthogneisses of the granulite zone at Nordlandet are predominantly statically recrystallised dark brown, greasy, typical orthopyroxene granulites. Both heterogeneous 
and homogeneous phases are present, although gneiss relationships are more obscure. After a sharp transitional contact with amphibolite facies gneisses there is a marginal zone approximately $2 \mathrm{~km}$ wide characterised by alternating granulites and rocks which show no evidence of granulite facies metamorphism. Within the granulites, the mixed gneisses and Kûa pre-granulite facies migmatite phase of Macdonald (1974) can be recognised. The migmatites occur as net-veined intrusions, agmatites and thick sheets which increase in proportion toward a large intrusive elliptical granite body forming the core of a domal antiform just west of Sârdlup taserssua. The correlation of the late homogeneous Nûk granodioritic phase and the Kûa migmatites is rather speculative.

A distinct suite of late pink and white coarse granitic pegmatites is found extensively intruding the Malene supracrustal pile, especially on the central and northern plateaus of Bjørneøen. These pegmatites are also found to a lesser extent intruding Nûk gneisses in Bjørneøen and the gneisses and granulites of Nordlandet. The pegmatites are mainly flat-lying sheets and are characterised by ubiquitous, small, bright red garnets.

\section{Structure}

All of the supracrustals, gneisses and granulites are deformed to a greater or lesser extent, and at least three major deformation phases can be recognised.

The recognition of $D_{1}$, the earliest structures, in an area of such marked chronological, stratigraphical and structural diversity is an extremely complex problem in itself. $D_{1}$ may conveniently be used as a comprehensive term to include such events as the formation of much of the metamorphic banding in the gneisses and the production of the frequent mostly highly attenuated intrafolial isoclinal folds and early closed structures affecting this banding and also occasionally the supracrustal layering. Within this deformation stage may also be placed the probably mostly tectonic juxtaposition of the major supracrustal and gneiss units.

The next major phase affecting all of the lithologies, $D_{2}$, parallels the banding in the supracrustals and layering in the gneisses and is mostly an intense $L S$ tectonic fabric. This fabric appears to have been originally nearly flat-lying with a strong eastwest component. Within the supracrustals the fabric forms a pervasive mineral cleavage in which objects such as feldspar clots in the amphibolites, and coarse metagabbroic textures are flattened, also with elongation parallel to the mineral lineation. Within the gneisses, the fabric is shown by the preferred orientation of inequidimensional stretched quartz leaves, feldspar augen (now finely recrystallised) and oriented hornblende and biotite crystals. This mostly intense fabric probably caused the break up and boudinage of many of the supracrustal bands within the more ductile gneisses.

The $D_{2}$ fabric is heterogeneous and shows a general decrease in intensity from east to west. $D_{2}$ folds are rarely observed, though some minor isoclinal asymmetrical folds with axes usually nearly parallel with the $D_{2}$ lineation occasionally occur in both the gneisses and supracrustals.

The banding and $D_{2}$ fabric are both deformed by a series of NE-SW trending, upright, open to tight and often angular folds, representing $D_{3}$. Axial planes generally dip moderately to steeply south-east and fold axes typically are moderately south plunging. However, horizontal and gentle northerly plunges commonly occur. The 
major stratigraphic distribution of the Bjørneøen lithologies and the complex pattern of outcrops in the northern exposures of the supracrustal pile are a direct result of the major and minor $D_{3}$ fold style. Major $D_{3}$ antiforms and synforms of a few kilometres in wavelength are recognisable over much of the area of Bjørneøen and east Nordlandet. The general low finite intensity of the $D_{3}$ deformation has led the relatively minor development of axial planar $D_{3}$ pervasive fabrics. These fabrics are only infrequently recognised within some of the folded pegmatites and in a few localities of buckled supracustals on the coast of Nordlandet, east of Kigssaviat.

The place of the major pegmatite suite within the deformation sequence is extremely significant as the pegmatites appear to have been intruded after the formation of the $D_{2}$ fabric, but, as mentioned, they are folded by $D_{3}$ and often contain a weak $D_{3}$ axial planar mineral fabric. The pegmatites mostly lie parallel to or slightly oblique to the $D_{2}$ fabric and banding. However, some are markedly discordant.

On the west coast of Bjørneøen, the steep western limb of a more intensely flattened $D_{3}$ antiform displays a moderate to strong, gently south plunging fold axis lineation. A similar lineation is frequently developed elsewhere in the Godthåbsfjord region, e.g. on the Godthåb peninsula, and is produced by the intersection of minor $D_{3}$ crenulation fold axes with a weak axial planar steep $D_{3}$ fabric.

\section{Mylonite zones}

Central Bjørneøen is dissected by two major, and one less persistent, steeply east dipping, mylonite ductile shear zones which trend NNE-SSW. These zones reach $30-40 \mathrm{~m}$ in true thickness and develop fine-grained, homogeneous and banded rocks. A characteristic pervasive mylonite foliation wraps around relic feldspar clasts and includes a prominant down dip lineation. Mylonite banding is frequently distorted by isoclinal and often interfolial flexural flow folds and ptygmatic structures.

From the asymmetry of minor fold vergence and from the sense of warping of the external fabric into the zones, a steep, over-thrust from the east is indicated.

The mylonitic zones are laterally persistent and trend slightly obliquely to the $D_{3}$ major fold traces. However, they may possibly be related to a late or just post $D_{3}$ phase of heterogeneous ductile deformation. Pseudotachylite veins, occasionally developed cutting the mylonites, may also represent late stage brittle deformation concentrated in the more active mylonite zones.

Within the amphibolite and granulite grade gneisses of the coast of Nordlandet there are occasional $2-10 \mathrm{~m}$ wide mylonite shear zones of similar orientation and sense to the major ones. They are, however, less consistent, with frequent marked orientation and dip variations (generally less steeply inclined). They form pale retrogressive zones in the granulites and are probably equivalent to those described by Macdonald (1974).

\section{Later structures}

A variety of late subvertical major and minor semi-ductile and brittle shear dislocations affect both the gneisses and supracrustals of Bjørneøen and Nordlandet. These structures are occasionally followed and intruded by major dolerite dyke swarms. 


\section{Anomalous structures}

At the south-east tip of Bjørneøen, and in the west at Ivnârssúnguaq, steeply south plunging minor folds occur. These folds do not fit into the so far relatitely simple deformation scheme. Characteristically they contain steeply plunging markedly linear tectonic fabrics. Folds of this type are also found to the east of Kigssaviat on the Nordlandet coast, and a similar major steeply south plunging fold nose forms the peninsula of Nûgârssuk, east of Qugssuk. These enigmatic structures may possibly be related to the $D_{3}$ refolded cores of major $D_{2}$ flexures, or they may represent a variation in orientation of the banding caused by pre- $D_{2}$ deformation.

\section{Conclusions}

The sequence of possible events related to the evolution of the sequence of Bjørneøen and adjacent Nordlandet may be summarised as follows:

(1) Emplacement of early supracrustal sequence, mainly amphibolites into earlier (?) gneisses.

(2) Intrusion of heterogeneous early Nûk phase with related minor migmatite and vein intrusion. $D_{1}(?)$.

(3) Tectonic (?) emplacement of major Malene supracrustal pile on Bjørneøen.

(4) Intrusion of homogeneous granodiorite Nûk sheets from the east.

(5) $D_{2}$ formation of flat-lying plane strain fabric possibly related to simple shear movements caused by the emplacement of Nûk sheets from the east.

(6) Emplacement of a suite of coarse, thick pegmatites, mostly lit-par-lit.

(7) $D_{3}$ formation of upright major NNE-SSW folds.

(8a) Granulite facies metamorphism on Nordlandet during late $D_{3}$.

(8b) Development of steep narrow mylonite zones. Minor zones retrogressing the granulites.

(9) Late semi-ductile and brittle structures followed by major dyke swarms.

\section{References}

Bridgwater, D. \& McGregor, V. R. 1974: Field mapping on the early Precambrian rocks of the Godthåbsfjord region, southern West Greenland. Rapp. Gronlands geol Unders. 65, 39-44.

Macdonald, R. 1974: Investigations on the granulites of southern Nordland, Godthăbsfjord, central West Greenland. Rapp. Grønlands geol. Unders. 65, 44-49.

McGregor, V. R. 1973: The early Precambrian gneisses of the Godthåb district, West Greenland. Phil. Trans. R. Soc. Lond. A, 273, 343-358.

Noe-Nygaard, A. \& Ramberg, H. 1961: Geological reconnaissance map of the country between latitudes $69^{\circ} \mathrm{N}$ and $63^{\circ} 45^{\prime} \mathrm{N}$, West Greenland. Map Grqnlands geol. Unders. 1 (also Meddr Gronland 123,5) 2 sheets, 9 pp.

Dept. of Earth Sciences, University of Leeds, Leeds LS2 9JT, U. K. 